\title{
PERFORMANCE AND POTENTIAL USE OF SUBTERRANEAN CLOVER STRAINS IN NEW ZEALAND
}

\author{
M. L. Smetham \\ Lecturer in Agronomy, Lincoln College
}

\section{INTRODUCTION}

Commenting on the discovery of subterranean clover in $\mathrm{New}$ South Wales in 1896, Mr Maiden, Botanist to the State Government, wrote: "This is not an introduction which need render us uncomfortable." In making this statement, he could scarcely have foreseen that there would be an estimated 20 to 30 million acres of sown subterranean clover pastures in Australia by the 1950s (Davies, 1952).

In N ew Zealand, the need for this plant, adapted as it is to areas of 15 to $25 \mathrm{in}$. annual rainfall and regular summer droughts, is relatively small. Nevertheless, by 1954 usage of seed had steadied at 200 tons annually (Saxby, 1956) and an estimated 140,000 acres were being newly sown to subterranean clover each year. The strains used were almost exclusively Mt Barker (mid-season) and Tallarook (late-season) with some Bacchus Marsh.

\section{Differences Between STrains}

Although variation within a strain is not great, differences among strains of Trifolium subterraneum are very noticeable, especially regarding the date at which flowering starts.

Being an annual, regeneration is vital not only for survival but also for the success of a strain, and this is primarily dependent on a good seed set. Strains show large differences in seed-setting ability, more particularly under moisture stress conditions. Yates (1961), looking at seed set in various strains, concluded that in the drier area of Australia earlier flowering strains set more seed because they flowered before serious drought set in. In addition. they buried a higher proportion of seed in the ground compared with later strains, thus helping seed maturation. In these areas, later flowering strains were unable to ripen 
enough seed for survival. However,' in moist environments, late strains were superior in flowering and seed setting.

\section{Strain EVAluation IN NEW Z Zatand}

Many strains are now known in Australia. For instance, Gladstones (1966) described 89 occurring in Western Australia alone, all having different characters. In view of this great diversity, it is surprising that few comprehensive strain evaluations have been conducted in New Zealand.

Levy and Gorman (1936) were the first to compare a wide range of strains in New Zealand. They found the early mid-season flowering Burnerang, Myall (synonymous with Bacchus Marsh), and Nangeela (late mid-season) to be most winter-active and most productive at all seasons, with Mt Barker of the mid-season group worth sowing but of only fair production. Tallarook (synonymous with Bena), a lateflowering strain, produced well but late in the season. In spite of Levy and Gorman's demonstration that the most productive and useful group was to be found mainly among the early mid-season strains, Mt Barker and Tallarook have been the only ones widely used in New Zealand, the sole reason being, it seems, that seed has been readily available.

Since 1937, the Department of Agriculture has been looking at strains of subterranean clover throughout New Zealand, 80 strains having been tested. Results show that Woogenellup and Bacchus Marsh (both early mid-season) with Nangeela have almost always outproduced the standard Mt Barker and other strains ( $P$. B. Lynch and L. D. Bascand, pers. comm.). More recently, in cutting experiments, W. R. Lobb (pers. comm.) at Winchmore, McLeod (1966) near Timaru, and A. J. Harris (pers. comm.) in northern Southland all found that Woogenellup gave superior annual production to Mt Barker. Bacchus Marsh in Southland and Nangeela at Winchmore were also highly productive. Recent Lincoln College work in North Canterbury has shown that Mt Barker is inferior to other strains for winter growth.

\section{CENTRAL OTAGO TRIALS}

In parts of Central Otago, with 15 to 20 in. rainfall and semi-arid climate, there is great difficulty in maintaining perennial clovers. Annual clovers such as subterranean may have a great potential in this region; but prior to 
1965 no serious evaluation had ever been attempted. In 1965, the writer commenced comparisons of 18 strains covering a range of early to late flowering dates. The strains were chosen from those which showed promise in earlier Department of Agriculture trials elsewhere.

\section{ME T HOD S}

Seeds 'were sown in February, 1965, in prepared seedbeds at three sites near Cromwell, Tarras and Wanaka, where the 20-year average rainfall at adjacent meteorological stations was, respectively, 16.5, 17.5 and 25.1 in. per year. Seventy seeds of each strain were sown $3 / 4$ in. deep in $5 \mathrm{ft}$ rows spaced $3 \mathrm{ft}$ apart. All rows were randomized and replicated twice. Two hundredweight of reverted superphosphate was sown with the seed and more phosphate, sulphur and lime were applied that winter. Phosphate was applied annually in later years (see Appendix 1).

The strains were scored separately for density and amount of growth on a 0 to 10 scale, at least four times a year and in each season, over a three-year period. Assessments were made of leafiness, spread and approximate period of flowering (see Appendix). Monthly rainfall was noted at each site.

\section{RESULTS}

Results for the second and third years only have been considered, since it was not until the second year that dense swards were obtained. Both Yates (1961) and Rosșiter (1959) have shown that sward density has a big influence on seed set in subterranean clover. Consequently, meaningful measurements of seed-setting ability and subsequent production could only be made on the second and third year swards.

The most outstanding result was that in all seasons at all sites several, and sometimes as many as six strains outproduced Mt Barker by $20 \%$ or more.

\section{AnNuA PRODUCTION}

Mean annual production combined for all sites showed that two strains, Woogenellup (synonymous with Burnley and Marrar) and Nangeela outproduced Mt Barker very substantially (Table 1). 
TABLE 1: MEAN ANNUAL PRODUCTION, 1966 AND 1967, ALL SITES COMBINED

(Relative to Mt Barker 100)

\begin{tabular}{|c|c|c|c|c|c|c|c|}
\hline $\begin{array}{l}\text { Woogenellup } \\
\text { Nangeela } \\
\text { Mt Barker"', }\end{array}$ & $\begin{array}{l}\cdots \\
\cdots \\
\cdots\end{array}$ & $\begin{array}{l}\cdots \\
\cdots \\
\cdots\end{array}$ & $\begin{array}{l}\cdot \\
\cdots \\
\ldots\end{array}$ & $\begin{array}{l}\ldots \\
.\end{array}$ & $\begin{array}{l}\cdots \\
\ldots\end{array}$ & $\begin{array}{l}\cdots \\
\cdots\end{array}$ & $\begin{array}{l}151 \\
141 \\
100\end{array}$ \\
\hline
\end{tabular}

When individual sites were considered, a greater number of strains performed well. In addition to Woogenellup and Nangeela, which gave outstanding production at Wanaka, Bacchus Marsh, Wenigup, Bena and Tallarook also outproduced Mt Barker at some sites (Table 2).

TABLE 2: MEAN ANNUAL PRODUCTION FOR EACH SITE, 1966 AND 1967

(Relative to Mt Barker 100)

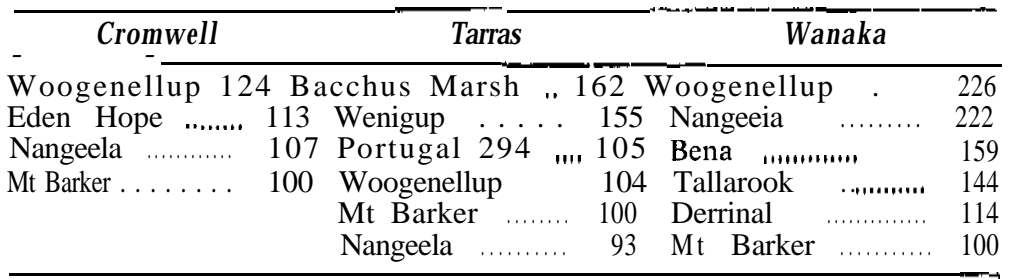

\section{SeAsonal PRODUCtion}

The mean seasonal production ranking showed that Woogenellup was the only strain which was consistently higher producing than Mt Barker in each of the four seasons of the year (Table 3). Nangeela was superior except

TABLE 3: MEAN SEASONAL PRODUCTION, 1966 AND 1967, ALI SITES COMBINED

(Relative to Mt Barker 100)

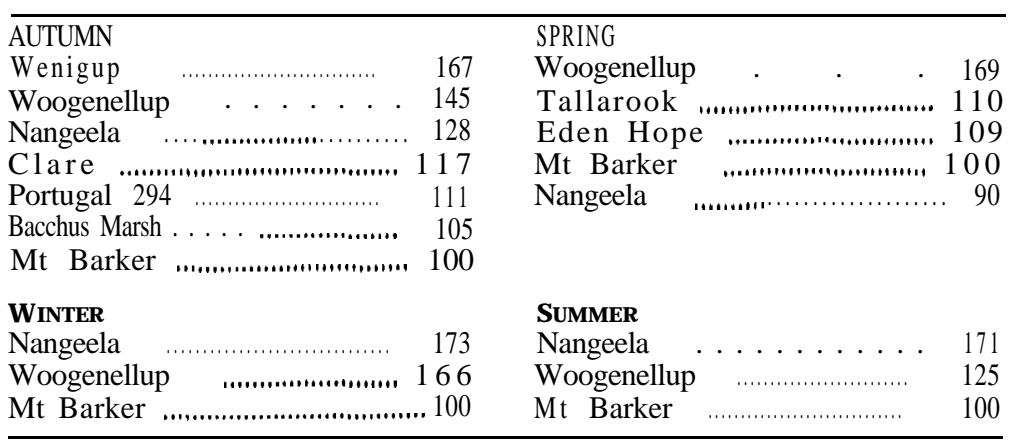


in spring, while Wenigup was outstanding in autumn. Others which were not as good but which showed promise were Clare, Portugal 294 and Bacchus Marsh in the autumn, and Tallarook and Eden Hope in the spring.

\section{Effect of Climate on Strain Performance}

Although in the first year the early-flowering group Dwalganup, Geraldton and Yarloop all performed tolerably well, subsequent production was very poor, mainly because of unsuccessful regeneration. This was possibly due either to frosting of the flowers, or to the lack of seed dormancy, mentioned by Morley (1958) as being characteristic of this flowering group, allowing premature and ill-f ated germination.

Several strains, including Woogenellup and Nangeela, re-established much better than Mt Barker (Table 4) and this contributed substantially to their good production.

TABLE 4: MEAN OVERALI DENSITY RANKING IN FEBRUARY OR MARCH, 1966 AND 1967

(0-10 score)

\begin{tabular}{lllllllll}
\hline Nangeela $\ldots . .$. & $\ldots$ & & $\ldots$ & $\ldots$ & $\ldots$ & & 5.9 \\
Woogenellup & $\ldots$ & & $\ldots$ & $\ldots$ & $\ldots .$. & & 5.8 \\
Bena and Bacchus Marsh & $\ldots$. &. & $\ldots$ & $\ldots$. &. &. &. & 4.7 \\
Mt Barker . . . & $\ldots$ & $\ldots$ & $\ldots$ & $\ldots$ & $\ldots$ & $\ldots$. & $\ldots$. & 4.4 \\
\hline
\end{tabular}

At the different sites (see Appendix 2), there was a definite trend towards greater density in the late midseason and late-flowering strains at the wetter site Wanaka. Here re-establishment of the late mid-season strains Nangeela, Derrinal, Burnerang and Tallarook $\mathbf{x}$ Wenigup and the late strains Bena and Tallarook were better than at the other sites. This implies that more seed was able to mature because of the better moisture conditions. It could also suggest that there was less seedling mortality at Wanaka in the autumn, although no deaths were noticed at either of the drier sites. This trend towards better establishment of late-flowering strains in wetter areas tends to support the findings of Australian workers mentioned earlier. No connection between strain or flowering group and rainfall was noticed either for total or seasonal production, with the exception that the 
late strains produced better than Mt Barker only at the wetter site.

In summary, the most successful strains at all sites were those in the early-mid, mid and late-mid season flowering groups. The late group performed well only at the wettest site, and those in the early group were the poorest of any strains tried.

\section{EFFECT OF FROST}

Frost did not cause any appreciable loss of plants or top growth. In the year of establishment, a few young plants were frost-heaved but this occurred only where plant density was low. In the same year, a little frosting of foliage occurred at Cromwell, while much frosting was experienced at the Wanaka site. In subsequent years, no severe frosting was noticed at any site. The frost effects in 1965 may therefore have been seasonal, especially since considerably more frosts than usual were experienced in July, August and September of that year. For example, at the Wanaka site a fortnight of ground frosts estimated to be greater than 18" occurred in early September, 1965. The fact that 104 ground frosts of more than $10^{\circ}$ were recorded at the Cromwell site in 1965 and only slightly fewer in 1966 and 1967 would indicate that subterranean clover is not unduly susceptible to frosting. When frosting was noticed, the strains affected were invariably Geraldton, Dwalganup, Clare, Nangeela, Wenigup, Tallarook x Wenigup and Rutherglen.

\section{TIME OF FLOWERING}

In general, the season of flowering of the well-known strains in the trials agrees with that found in Australia and mentioned by Higgs (1962). The early ones commenced flowering about the end of September and the late strains about mid-N ovember. Woogenellup proved to be a mid-season flowering strain' commencing in midOctober, and Nangeela late mid-season starting in late October (see A ppendix 3).

\section{THE FUTURE FOR SUBTERRANEAN CLOVER}

What part will subterranean clover play in the future? On a shallow stony soil at A shley Dene, Iversen (1965) showed that, with rotational grazing, lucerne will give 
more than double the dry matter yield of Mt Barker and Tallarook-based swards and with less annual variation. These findings are applicable to all of the light land in Canterbury. Because of this, the writer considers that, in the future, use of subterranean clover will be'restricted to those areas where, because of droughty summers, white clover is neither persistent nor very productive, and in which lucerne is desirable but not persistent or where it is impossible to establish.

Which strains of subterranean clover should be used?

In view of the weight of corroborated evidence, it is suggested that, even at this early stage of testing, farmers could with advantage be encouraged to use Woogenellup and Nangeela, and possibly also Bacchus Marsh in the same sward. The range of flowering periods will give some insurance against adverse climatic effects.

The very good growth of some strains in the autumn and particularly in winter should lead to a wider use of subterranean clover for the provision of feed in these periods. Some work needs to be done on the combination of summer-growing, rotationally-grazed lucerne, with winter-growing subterranean clover in the same sward, particularly since Iversen (1957) found an additive yield effect with set-stocked lucerne-subterranean. clover-grass pastures on light soils in Canterbury.

Again, subterranean. clover should be more widely used as a pioneer legume. Its large seed size confers the ability to establish quickly even when sown deeply as on a rough uneven seed-bed. This quick establishment and rapid early growth as compared with that of perennial legumes must mean a more rapid build-up of soil nitrogen so desirable when land is being developed.

However, in the main, increased use should be made of subterranean clover for the oversowing of sunny faces in hill country, where production from this legume is likely to exceed that from others.

More experimental work with the better strains of subterranean clover is needed, since their potential has to date been largely neglected.

\section{ACKN OWLEDGEMENTS}

This work was conducted initially under the aegis of the Department of Agriculture, and latterly while the author has been at Lincoln College.

Ground frost figures were kindly supplied by the N.Z. Meteorological Service. 


\section{References}

Davies, J. G., 1952: I. Aust. Insf. agric. Sci., 18: 60-7.

Gladstones, J. S., 1966: Aust. J. Bot., 14: 329-54.

Higgs, E. D., 1962: J. Agric. S. Aust., 65: 376-81.

Iversen, C. E., 1957: Canterbury (N.Z.) Agric. Bull. 332.

- 1965: Proc. Lincoln Coll. Fmrs' Conf., 15: 78-84.

Levy, E. B.; Gorman, L. W., 1936: Proc. N.Z. Grassl. Ass., 5: 19-33.

McLeod, C. C., 1966: N.Z. Dept. Agric. Ann. Rep. Field Res. Section, 1966/ ๑.

Morley, F. H. W., 1958: Aust.J. biol. Sci., 11: 261-74.

Rossiter, R. C., 1959: Aust. J. agric. Res., 10: 305-22.

Saxby, S, H., 1956: N.Z. I. Agric., 92: 518-27.

Yates, J. J., 1961: Aust. J. agric. Res., 12: 10-26. 
APPEN DIX 1

SITE DETAILS, FERTILIZERS AND WEED CONTROL

\begin{tabular}{|c|c|c|c|}
\hline & Cromwell & Wanaka & Tarras \\
\hline Altitude (above sea level) & $625 \mathrm{ft}$ & $1,200 \mathbf{f t}$ & $1,500 \mathrm{ft}$ \\
\hline Topography & flat & flat & 12" Slope N.W. \\
\hline Soil set & Molyneux B.G.E. & Criffel Y.B.E. & Waenga B.G.E. \\
\hline $\begin{array}{l}\text { Soil quicktest prior to sow- } \\
\text { ing. Previous treatment. }\end{array}$ & $\begin{array}{l}\text { pH:5.9, Ca: } 3, \mathrm{~K}: 16, \mathrm{P}: 7 . \\
\text { Cultivated out of virgin } \\
\text { state. No fert. last } 10 \mathrm{yr} \\
\text { at least. }\end{array}$ & $\begin{array}{l}5.0,3,6,81958-62 \text { poor } \\
\text { pasture. } \\
19621 \text { cwt super. } \\
1963 \text { grubbed. } \\
1964 \text { sown to turnips with } \\
1 \text { cwt reverted super. }\end{array}$ & $\begin{array}{l}5.3,5,25,8 \text { Cultivated out } \\
\text { of native pasture. No fertilizer } \\
\text { for at least } 5 \mathrm{yr} \text {. }\end{array}$ \\
\hline $20 \mathrm{yr}$ average rainfall (in.) & 16.5 & 25.1 & 17.5 \\
\hline Sowing date & Feb. 17, 1965 & Feb. 17, 1965 & Feb. 18,1965 \\
\hline \multicolumn{4}{|l|}{ Fertilizers } \\
\hline $\begin{array}{l}2 \mathrm{cwt} \text { reverted super. at } \\
\text { sowing }\end{array}$ & Feb. 17, 1965 & Feb. 17,1965 & Feb. 18,1965 \\
\hline $\begin{array}{l}1 \text { ton lime } \\
11 / 2 \mathrm{cwt} \text { sulphur super. } \\
\text { (equiv.) applied as ibex } \\
\text { sulphur and gypsum }\end{array}$ & Aug. 18, 1965 & Aug. 24, 1965 & Aug. 25, 1965 \\
\hline $\begin{array}{l}2 \text { cwt straight super. } \\
2 \text { cwt straight super. }\end{array}$ & $\begin{array}{l}\text { Aug. 21, } 1966 \\
\text { April, } 1967\end{array}$ & $\begin{array}{l}\text { Sep. 15, } 1966 \\
\text { April, } 1967\end{array}$ & $\begin{array}{l}\text { Sep. } 14,1966 \\
\text { April, } 1967\end{array}$ \\
\hline Soil quicktest Oct. 31, 1967 & $\mathrm{pH}: 7.0, \mathrm{Ca}: 5, \mathrm{~K}: 10, \mathrm{P}: 17$ & $6.0,5,4,16$ & $6.7,5,16,14$ \\
\hline \multicolumn{4}{|l|}{ WEED CONTROL } \\
\hline $\begin{array}{l}\text { Hand-weeded and hoed } \\
\text { Sprayed } 11 / 2 \text { pints } \\
\text { paraguat }+3 \mathrm{pt} \text { Agral }\end{array}$ & May 14,1965 & May 5, 1965 & May 5, 1965 \\
\hline LN in $100 \mathrm{gal}$ water/a\% & May $\overline{4,} 1966$ & $\begin{array}{l}\text { May } 5,1965 \\
\text { May } 2,1966\end{array}$ & May $\overline{2,} 1966$ \\
\hline
\end{tabular}


APPENDIX 2

MEAN PLANT DENSITY SCORE (O-10) IN AUTUMN, 1966 AND 1967

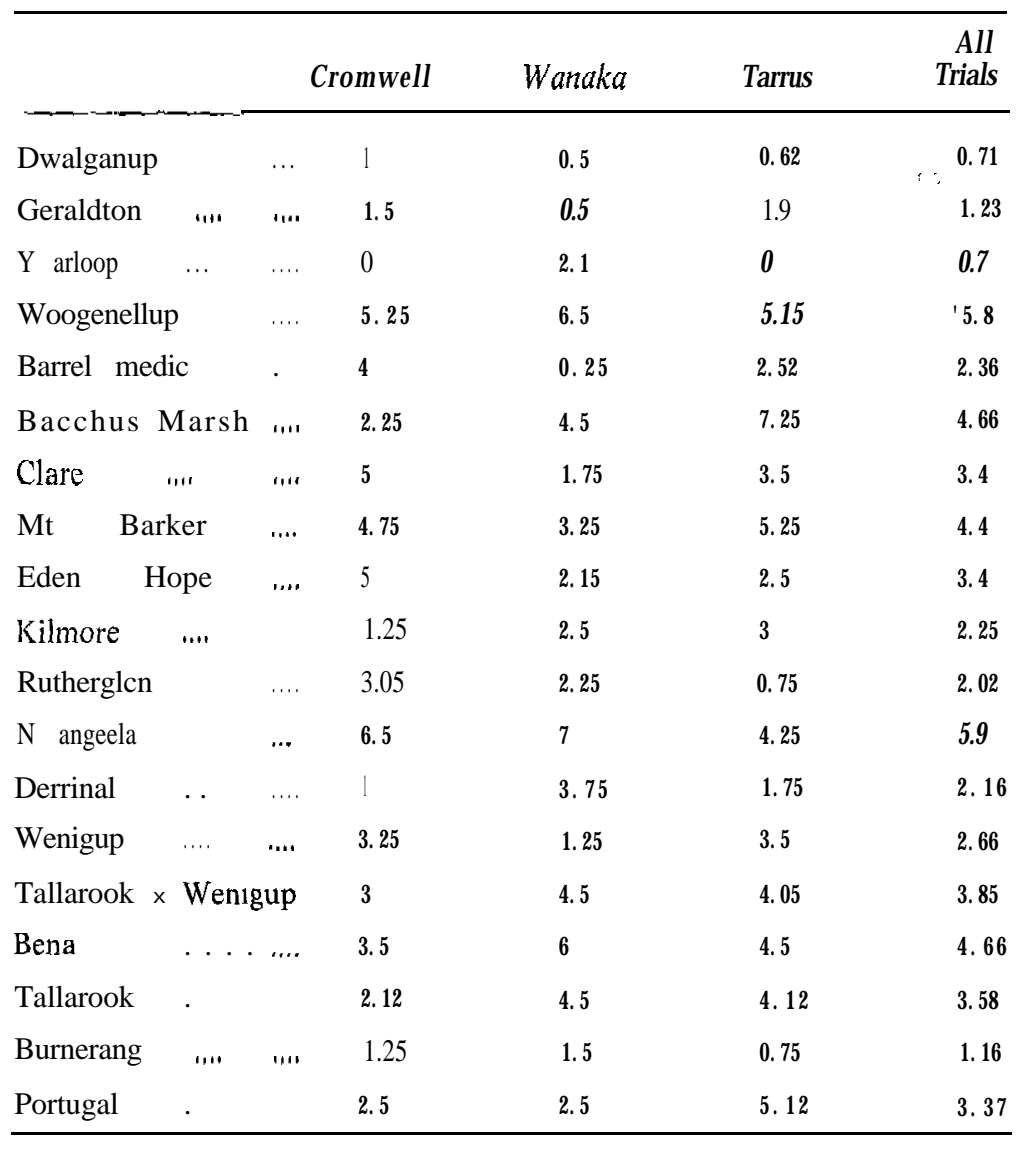

Figures in bold type indicate that the strain is equal to or better than Mt Barker. 


\section{APPENDIX 3}

\section{OBSERVED STRAIN CHARACTERISTICS}

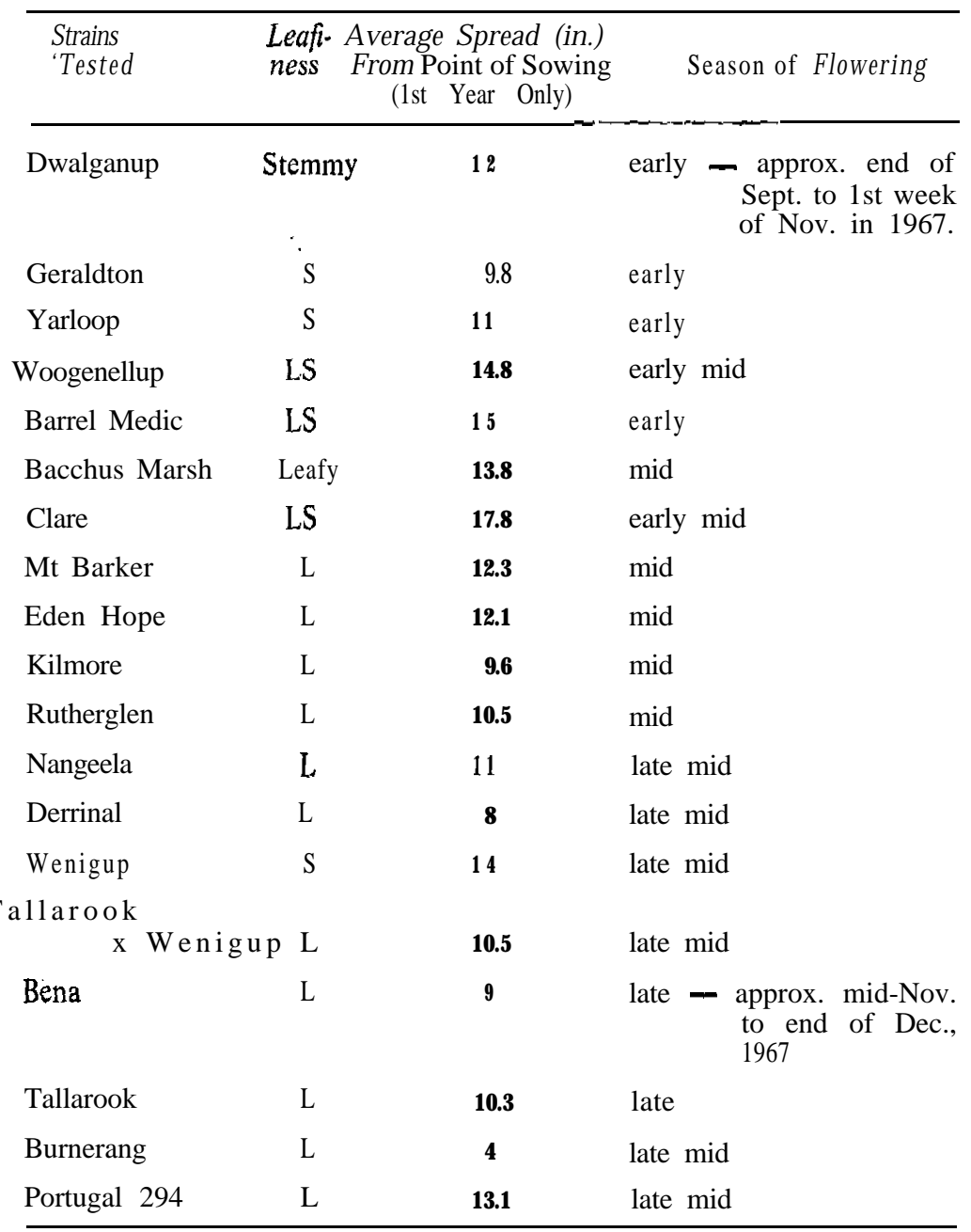

$\mathrm{LS}=50: 50$ leaf: stem 
RELATIVE PRODUCTION AT EACH SEASON APPENDIX 4

(Mean of 1966 and 1967 Readings Only)

\begin{tabular}{|c|c|c|c|c|c|c|c|}
\hline \multicolumn{8}{|l|}{ Cromwell } \\
\hline Autumn & & Winter & & Spring & & Summei & \\
\hline Woogenellup & 162 & Woogenellup & 112 & Eden Hope , & 148 & Nangeela & 142 \\
\hline Clare $\quad$................................ & 130 & Mt Barker …, & 100 & Nangeela $\quad \ldots$ & 109 & Woogenellup & 130 \\
\hline Wenigup $\quad$........................ & 102 & .................. & 96 & Mt Barker. & 100 & Eden Hope ……………............ & 119 \\
\hline Mt Barker ...................... & 100 & & & Woogenellup & 92 & Mt Barker ........................... & 100 \\
\hline Eden Hope .................. & 98 & & & & & Portugal $\quad$................................. & \\
\hline \multicolumn{8}{|l|}{ TARRAS } \\
\hline Autumn & & Winter & & Spring & & Summer & \\
\hline Wenigup $\quad . . . . . .$. & 237 & Bachus Marsh & 172 & Wenigup $\quad$........................... & 153 & Bacchus Marsh & 128 \\
\hline Bacchus Marsh ........... & 198 & Woogenellup & 157 & Bacchus Marsh …......... & 150 & Nangeela $\quad$............................... & 114 \\
\hline Clare $\quad$.............................. & 121 & Wenigup $\quad$........................... & 136 & Portugal $\quad$................................ & 142 & Portugal ……………….......... & 108 \\
\hline 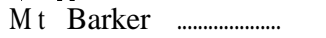 & 100 & Mt Barker …..................... & loo & Nangeela $\quad$.......................... & 113 & Woogenellup & 105 \\
\hline Portugal $\quad$....................... & 69 & Portugal $\quad$.......................... & 99 & Mt Barker, Clare & 100 & Mt Barker & 100 \\
\hline & & Clare ……………............ & 98 & Woogenellup $\quad$................ & 94 & Wenigup $\quad$............................ & .94 \\
\hline & & Nangeela $\quad$......................... & 96 & & & & \\
\hline \multicolumn{8}{|l|}{ WANAKA } \\
\hline Autumn & & Winter & & Spring & & Summer & \\
\hline Nangeela . & 256 & Nangeela . & 326 & Woogenellup & 320 & Nangeela & 258 \\
\hline Woogenellup & 216 & Woogenellup & 228 & Tallarook $\quad \ldots \ldots$ & 240 & Tallarook & 169 \\
\hline Yarloop \& Portugal . & 175 & Bena $\ldots \ldots$ & 198 & Bena & 200 & Woogenellup & 140 \\
\hline Wenigup $\quad \ldots . . . \ldots$ & 162 & Derrinal & 138 & Derrinal & 178 & Bena & 131 \\
\hline Tallarook $\mathrm{x}$ Wenigup & 133 & Tallarook ....................... & 127 & Eden Hope ...................' & 124 & Mt Barker ……..................... & 100 \\
\hline 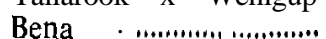 & 108 & Mt Barker . & 100 & Mt Barker . . . . . ................ & 100 & Eden Hope ……………............ & 76 \\
\hline Mt Barker & 100 & Rutherglen & 98 & Rutherglen $\quad \ldots . . . . .$. & 73 & & \\
\hline Zutherglen . & 93 & & & & & & \\
\hline
\end{tabular}




\section{DISCUSSION}

Asked whether time of sowing could have caused unsatisfactory establisment, Smetham agreed this could be so, as cold treatment was necessary for floral initiation and so autumn-sowing gave best results, particularly for mid- and late-season varieties. It was perhaps not so vital for earlyflowering types.

To a comment on the oestrogen content of subterranean-clover and its effect on fertility, Smetham said that no evidence was available of this in New Zealand. Calder had found no adverse effects at Ashley Dene. However, before using new strains, he felt this aspect should be considered, since the oestrogenic effect was permanent once it had occurred and so could be most serious. Here Crofts (University of Sydney) commented that Woogenellup was better than Mt Barker and had almost completely replaced that variety in Australia. Woogenellup had a low oestrogen level and there was no record of its having caused trouble. More strains, especially Daliak, were becoming available and they had little or no oestrogen. He suggested that more varieties should be tested in New Ze?land, particularly where failures to establish had occurred.

As far as the nitrogen-fixing ability of strains was concerned, Smetham did not known of any work being done. It was pointed out that a comparison of $\mathrm{N}$-fixing abilities among white, suckling and subterranean (Mt Barker) clovers was being carried out at Grasslands Division by Brock.

To a question as to whether diseases, especially rust, had become a problem, Smetham replied that he had had' no note of rust, but that Mt Barker was very susceptible to stunt virus, while Tallarook appeared to be resistant. Crofts commented that Howard had been produced in Australia as a virus-free strain. However, Woogenellup and Daliak also proved to be resistant, with the result that Howard was not used to any extent.

Corkill added the comment that Gorman had tested a wide range of varieties, including Nangeela, and that all had succumbed to virus attack. It was admitted that the fat that the trials were not grazed constituted a serious drawback. However, the intention was to institute grazing trials in the near future. 